\title{
The Determinants of Profitability in Listed Enterprises: A Study from Vietnamese Stock Exchange
}

\author{
Thi Ngoc Lan NGUYEN ${ }^{1}$, Van Cong NGUYEN ${ }^{2}$
}

Received: September 10, 2019 Revised: November 01, 2019 Accepted: November 15, 2019

\begin{abstract}
The research aims to investigate the determinants of the financial performance of 1343 Vietnamese companies categorized into six different industries listed on the Vietnamese Stock Exchange over a four-year period from 2014 to 2017 using STATA software. Those determinants include firm size, liquidity, solvency, financial leverage, and financial adequacy while the financial performance is evaluated by three different ratios: return on assets (ROA), return on equity (ROE), and return on sales (ROS). The research results from these companies during the given period indicate that: (1) Firm size has a positive impact on both ROA and ROS, especially ROA but it has the opposite effect on ROE, (2) Adequacy ratio impacts positively on ROA and ROS but negatively on ROE, (3) Financial leverage considerably negative influences on ROE and ROS but positively impacts on ROA, (4) Liquidity has a positive effect on both ROA and ROE but a negative one on ROS and (5) Solvency has a positive impact on ROA and ROS but the negative impact on ROE. Furthermore, agriculture accounted for the highest percentage of profitability at the beginning, which was replaced by service for ROA but manufacture for ROE from 2016 to 2017 as opposed to the least in transportation.
\end{abstract}

Keywords : Profitability Determinants, Vietnamese Listed Enterprises, Vietnam Stock Exchange

JEL Classification Code : G31, G32, L25

\section{Introduction}

Profitability is one of the vital elements for performance evaluation, showing the proportion of profit in comparison with asset investment, equity, or sales. Improving profitability is one of the key tasks for enterprises, especially in the context of international economic integration today in Vietnam. Because only a stable economy with high profitability can provide enough financial resources for sustainable development, therefore, can attract attention and investment from internal and international investors. Not

1 First Author, MSc. Student, School of Economics, Finance and Management, the University of Bristol, United Kingdom. Email: nguyenthingoclan29071997@gmail.com

2 Corresponding Author, Professor, School of Accounting and Auditing, The National Economics University (NEU), Vietnam. [Postal Address: 207 Giai Phong, Dong Tam, Hai Ba Trung, Hanoi, 113068, Vietnam] Email: anhcongtuan@gmail.com or congnguyen@neu.edu.vn

(c) Copyright: Korean Distribution Science Association (KODISA)

This is an Open Access article distributed under the terms of the Creative Commons Attribution Non-Commercial License (http://Creativecommons.org/licenses/by-nc/4.0/) which permits unrestricted noncommercial use, distribution, and reproduction in any medium, provided the original work is properly cited. only being a reliable basis for evaluating business performance, profitability also is a useful tool for forecasting the performance of businesses in the future. Profitability reflects shareholders' wealth, and accordingly, appeals to investors. This is the reason why identifying different factors affecting directly or indirectly to profitability is an essential research theme in economics, strategic management, accounting and finance.

Over time, many researchers have paid attention to an optimal capital structure that progresses the enterprises' profitability (Bradley, Jarrell, \& Kim, 1984; DeAngelo \& Masulis, 1980; Miao, 2005). Besides, it is also necessary to classify other factors influencing directly to profitability such as financial leverage, solvency, liquidity, and financial adequacy. Many authors indicated eight different factors affecting the profitability in the enterprises, which are FIRM SIZE, capital structure, liquidity, solvency, sensitivity, the overhead cost to revenue ratio, and economic growth (Grau, \& Reig, 2018; Blažková, 2018; Fareed, Ali, Shahzad, Nazir, \& Ullah, 2016; Szymańska, 2017; Jumono, Sugiyanto, \& Mala, 2019; Mohanty \& Krishnankutty, 2018; Pattitoni, Petracci, \& Spisni, 2014; Yüksel, Mukhtarov, Mammadov, 
\& Özsarı, 2018). However, these findings are mostly established in developed countries with a significant economics gap comparing to Vietnam, leading to misappropriation in applying concepts. Additionally, these researchers mainly narrow their focus on a specific area of only one industry instead of tackling a vast array of fields. Therefore, the aim of this study is to carry out a broader empirical test, using both quantitative and qualitative methodology, to compare profitability in different industries, and to determine firm-specific determinants.

In order to overcome some of the above problems, this article will solve these problems by examining five internal factors include size, liquidity, solvency, financial leverage, and capital adequacy, which affect the profitability of the listed companies in Vietnamese stock exchange. Although other macro factors, which are economic growth, employment, innovation, and technological change, can explain the variation in profitability of a firm, these factors are assumed remaining stable in the given period, and therefore, can be ignored in this case.

Research data was collected from financial statements of 1343 companies listed on the Vietnamese stock exchange provided by the State Securities Commission of Vietnam. These companies were selected based on the availability of their annual reports between 2014 and 2017. To ensure the representativeness, completeness, and reliability of the collected samples, data was collected based on the following criteria:

Time period: The study period is between 2014 and 2017, when the Vietnam stock market witnessed positive changes in comparison with a downward trend in $\mathrm{VN}$-index between 2008 and 2012. This is because 2017 marked the beginning of unexpected success of Vietnam's economy when GDP accounted for $6.8 \%$, showing approximately $1 \%$ higher than the figure for the period of 2011-2016 with 5.96\% on average. Moreover, despite significant GDP growth, inflation is under control as a result of the Vietnamese Government's policy on prioritizing inflation management. The average CPI in 2017 increased only by $3.53 \%$ compared to 2016. This is a tremendous improvement in comparison with the crisis in 2008, when GDP increased to $8.48 \%$ and CPI rose to $8.3 \%$, leading to the transformation in listed companies in Vietnam.

The industries: Observations are based on the financial statements collected from 1343 listed companies in Vietnam stock exchange, categorized into six different industries: Wholesale and retail, manufacture, mining, agriculture, transportation, and service. The classification is based on the documents that Ho Chi Minh Stock Exchange announced.

The sources: Research data is collected from secondary data published publicly by the State Securities Commission and securities companies. Therefore, this data ensures the reliability, transparency and accuracy (Cafef, 2018; Cophieu68.vn, 2018; Hanoi Stock Exchange, 2018; Ho Chi Minh Stock Exchange, 2018; VietstockFinance, 2018).

The number of observations: With 1343 surveys (accounting for $100 \%$ of the sample size), 5372 observations are conducted to get the best estimate. On that basis, a regression model is established for analysis and verification with the help of specialized software STATA version 2015.
Research concentration
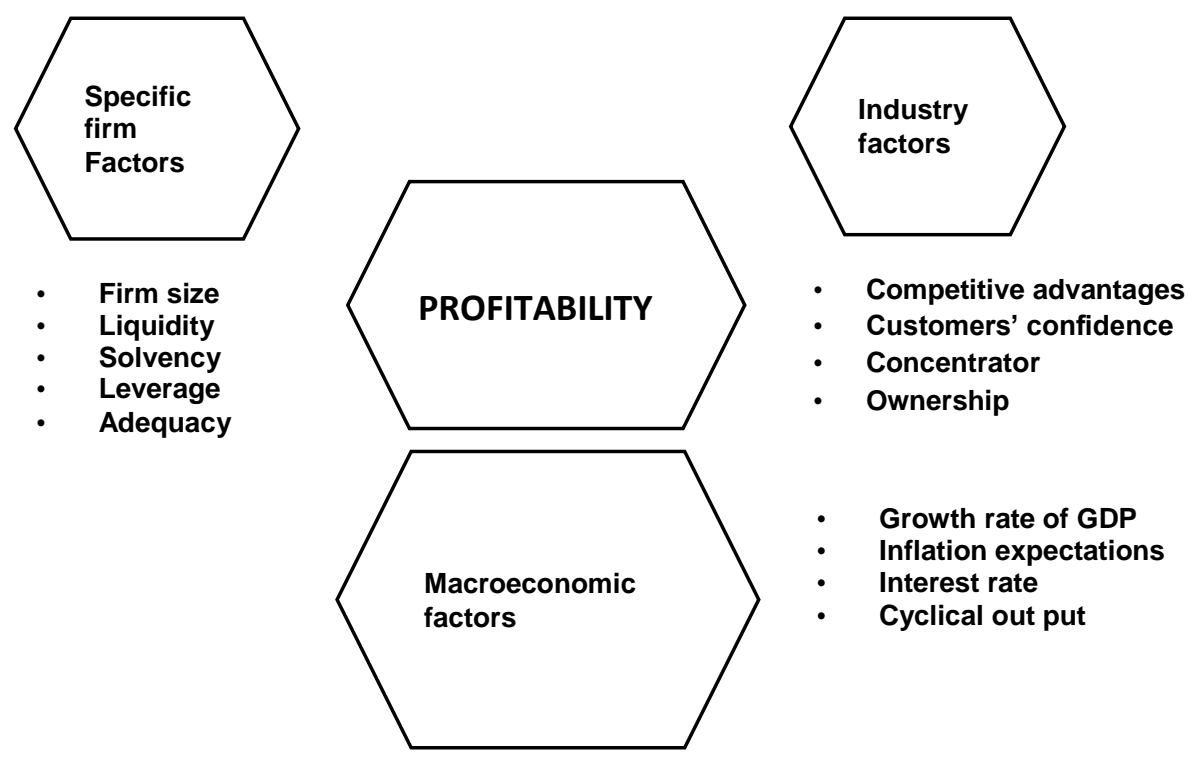

- Growth rate of GDP

- Inflation expectations

- Interest rate

- Cyclical out put 


\section{Literature Review}

Many studies examining the determinants of profitability have been done in listed enterprises, especially in a particular industry such as banking, insurance, manufacture, or real estate. The findings indicate that there are three different categories that those determinants can be classified into: Intentional firm variables, industry variables, and economics environment variables in accordance with several theoretical perspectives. The most famous five theories which can be applied for finding the factors affecting the profitability as well as business performance are: Marketbased view (MBV), the resource-based view (RBV), the strategy structure performance (SSP), the structure conduct performance (SCP) and the organization environment structure performance (OESP).

In MBV, many authors believe that the competitive advantages of a firm are generated mostly by the industrial organization economics, taking benefits from external market to achieve higher returns which are measured by the profitability and the firm values (Chamberlain, 1962; Gilbert, 1989; Molloy \& Barney, 2015; Zheng, Liu, \& Huang, 2019). In contrast - in RBV - it can be said that the profitability is provided as a result of the distinct of different resources such as human resources, machines, and technology, leading to a significant difference in the research results (Bromiley \& Rau, 2016; Grant, 1991; Hitt, Xu, \& Carnes, 2015; Peteraf, 1993; Wernerfelt, 1984). Researchers with SSP view, think that a firm's strategy, created in consideration of external environmental factors, drives the development of organizational structure and processes, then helps the firm with better performance than competitors who lack the same degree of strategic fit (Defee \& Stank, 2005; Galbraith \& Nathanson, 1978; Galunic \& Eisenhardt, 2000; Miles, Snow, Meyer, \& Coleman, Jr., 1978). The research results of the SSP theory illustrate that the market environment can influence directly and considerably on the market structure, resulting in the significant impact on the firm's value (Chamberlain, 1962; Edward, 1933; Kuenne, 1967; Robinson, 1933). Furthermore, many external factors including legal political interventions affect the market framework and, by extensionally, the structure, conduct and performance of the market.

Finally, developed Child (1972) OESP states that for all businesses, the super-ordinated goals which are evaluated by shared values mainly rely on six different organizational environmental factors (6S): Strategy, structure, systems, staff, style, and skills. Similarly, Cosh, Fu, and Hughes (2012), Lenz (1980) indicated that performance of enterprises is varied in accordance with a combination of environment, strategy, and organization structure; and the reason why some organizations achieved higher performance than the others is due to the differences in these four factors. They ensured that such combinations differ, the achieved performances of different enterprises are varied. Additionally, they found many statistic evidence to ensure that those four factors are "norms held by managers of competing institutions and are the nature of the relationship between organizations and populations served to influence the vigour and form of interfirm and, in turn, organization performance" (Lenz, 1980).

Empirical studies also classified the different factors responsible for the profitability into two major groups. The first group contains internal factors such as financial leverage, financial solvency, financial adequacy, financial independence, liquidity, firm size, growth, capital structure, firm ages, and other management decisions (Anbar \& Alper, 2011; Aburime, 2009; Blažková, 2018; Capon, Farley, \& Hoenig, 1990; Grau \& Reig, 2018; Huang \& Song, 2006). The second group takes concentration on the external factors classified into two different indicators: industrial-level indicators and macro-level indicators. While industrial-level indicators include market concentration, sector growth rate, and growth rate of imports, macro-level indicators contain the growth rate of Gross Domestic Product, inflation, interest rate, financial market returns (Grau \& Reig, 2018; Pattitoni, Petracci, \& Spisni, 2014).

According to Szymańska (2017), the ROE of pork manufacturing companies is determined by the high fragmentation of the industry, limited specialization, and customer confidence. Particularly, the author used the detailed annual financial statements of 86 meat companies in Poland from 2008 to 2012, then calculated the profitability through five different ratios, which are the ROA, ROE, ROS, assets turnover ratio, and equity multiplier before making a comparison among the given enterprises. She concluded that the most important internal factors affecting the profitability of these companies are the company's assets value and structure, liquidity, sale development, capital structure, working capital management efficiency, production process organization, and employee quality. Nevertheless, the external factors shaping the profitability of meat enterprises are climate, policy, legal systems, business cycle, interest rate, and inflation rate. Likewise, Sivathaasan, Tharanika, Sinthuja and Hanitha (2013) study the factors affecting the profitability of all manufacturing companies listed on the Colombian and Sri Lankan stock exchanges from 2008 to 2012. The independent variables (influencing factors) used for the research are capital structure, asset structure, company size, and growth rate, while dependent variables representing the profitability are ROA and ROE. In which, only capital structure has a positive impact on the profitability of companies, while the structure of assets, company size and growth rate have no effect on ROA and ROE.

Lazaridis and Tryfonidis (2006) collected data from 131 companies listed on the Athens Stock Exchange in the period 2001 - 2004 to find out the relationship between capital structure and profitability. The research results show that the cash conversion cycle and debt ratio have the opposite effect on the profitability of the business, as opposed to the positive impact of firm size and the ratio of fixed assets to total assets. Alshatti (2015) conducted research on 13 commercial banks in Jordanian in the eight- 
year period from 2005 to 2012 in order to evaluate the relationship between solvency and profitability. Findings show that the quick solvency ratio and investment ratio have a positive impact on the profitability of banks, while the equity ratio and instant solvency ratio are, on the other hand, negative factors. Evaluating the relationship between working capital management and profitability, Gill, Biger, and Mathur (2010) studied 88 companies listed on the New York Stock Exchange between 2005 and 2007. The results show that the average collection period, debt ratio, and fixed assets ratio negatively affect the profitability of the business whereas the revenue growth is on the reverse pattern.

In Vietnam, the number of researches investigating the determinants of profitability is very small. Research by Dong and Su (2010) focused on the influence of fixed asset ratio, cash conversion cycle, average collection period and inventory turnover on the profitability of listed companies in Vietnam's stock exchanges in the period from 2006 to 2008. They concluded that the cash transfer cycle has a negative impact on the profitability of enterprises in comparison with positive impact generated from fixed asset ratio, and average collection period. Tu and Nguyen (2014) used regression analysis of panel data collected from 208 listed companies on both Ho Chi Minh City Stock Exchanges and Hanoi Stock Exchanges to examine the relationship between working capital and profit management in the period from 2006 to 2012. Research results found that the cash conversion cycle plays a significant role in influencing the profitability of businesses.

In summary, the results of the literature review above have shown that most studies took concentration dominantly on a specific industry and on some specific factors affecting profitability. However, profitability is subjected to simultaneous effects of many factors and profitability is varied across sectors. This has led to a lack of extensive and comprehensive research on the economy as a whole and a specific comparison among different industries' profitability. In fact, both practical and theoretical researches conducted in developed countries indicate that the relationship between the internal factors and profitability has existed, but the researching methods and conclusions of different researches are still conflicted. Furthermore, since Vietnamese listed companies represent distinct characteristics with noticeable differences in comparison with international markets, it is necessary to have a new theoretical and practical concept for determining the profitability determinants. Therefore, this research will solve the contraries in previous researches and create a new model focusing on the impact of internal factors on profitability in different industries. These factors are size, liquidity, solvency, financial leverage, and capital adequacy collected based on financial statements published in Vietnam stock exchanges. We pay special attention to make a comparison among different Vietnamese industries' profitability through ROA, ROE, and ROS ratio.

\section{Hypothesis, Empirical Model and Research Methods}

\subsection{Hypothesis}

H1: Firm size is positively correlated with profitability.

In their research, Nanda and Panda (2018) have focused on finding the firm-specific and macroeconomic determinants of profitability in manufacturing companies by gathering the information collected on the Indian stock market between 2000 and 2015. The empirical models showed that: The firm size enhances the financial performance according to the significant increase in ROA as well ass net profit margin. Similarly, Babalola (2013), Baumol (1985), Blundell, Griffith, and Reenen (1999), Doğan (2013) agree with this hypothesis since they believe that an increase and upgrade in the financial capital can help the enterprise with capacity improvement, then market share extension before taking the competitive advantages to achieve higher profitability. Furthermore, it can be clearly seen that a larger firm always has more resources than a smaller firm, leading to a higher production scale, therefore, the larger firm can expect a higher return rate.

H2: Capital adequacy has a positive impact on profitability.

According to Ebenezer, Oma, and Kamil (2017), the capital adequacy is positively correlated with the profitability in sixteen commercial banks selected in Nigeria between 2010 and 2015. Similarly, Sufian and Habibullah (2009) examined the impact of capital adequacy on the profitability in banking sectors with 220 observations during the period of 5 years from 2000 to 2005, then they found out that a positive correlation between the capital adequacy and the profitability has existed. Having the same idea with previous researchers, Athanasogloua, Brissimisa, and Delis (2008) used SCP hypothesis with the support of GMM technique in order to illustrate that the capital adequacy positively significant influences ROA in Chinese commercial banks. This is because a bank with a sound capital position is able to pursue business opportunities more effectively and it has more time as well as the flexibility to deal with problems arising from unexpected losses, and therefore it is enabled to achieve higher profitability.

H3: Liquidity is positively correlated with profitability.

The studies of Deloof (2003), Nickell and Nicolitsas (1999), Pattitoni, Petracci, and Spisni (2014), Serrasqueiro and Nunes (2008) all have the same idea of the positive correlation between the liquidity and the profitability of enterprises. Particularly, Pattitoni, Petracci, and Spisni (2014) based on the research results of Goddard, Tavakoli, and Willson (2006) to develop four models with data collected from multi-industries and multi-countries and found that all 
four models illustrate a strong positive relationship between the independent variables measured by the liquidity ratio and the dependent variable measured by the ROE. This is because the "high level of liquidity can reduce the effects of adverse changes in the economic environment, the risk of being unable to repay short-term debts and the risk of losing profitable investment opportunities due to financial constraints" (Nickell \& Nicolitsas, 1999).

H4: Financial leverage has a negative impact on profitability.

According to Pattitoni, Petracci, and Spisni (2014), the more debt used, the fewer returns on equity is achieved. In fact, if the companies acquire more debt, they have to pay out more interest expense, leading to cash constraints due to periodic debt payments, then faced with financial difficulties before witnessing a decline in operating performance. Likewise, Ahmad, Salman, and Shamsi (2015) indicated that financial leverage has a statistically significant inverse impact on profitability at $99 \%$ confidence interval. This is due to the fact that the more debts companies acquired to finance assets, the more financial expenses they have to pay for interest, leading to remaining profit reduction, thereby reducing profitability. This hypothesis is conducted as a result of many previous studies (Benito \& Gertjan, 2000; Singapurwoko \& El-Wahid, 2011; Vintilă \& Duca, 2012).

H5: Solvency has a positive impact on profitability.

Based on the research findings of Alshatti (2015), it can be said that the solvency ratio positively affects profitability. This is because the higher the solvency would be, the greater the level of financial stability that enterprises could achieve, helping the enterprises with financial independence and financial security improvement. Thus, the enterprise would be able to progress productivity and efficiency, thereby achieving the goal of profitability enhancement.

\subsection{Empirical Model}

In this research, the authors will follow the method of quantitative research into regression models: firm size, capital adequacy, liquidity, financial leverage, and solvency are the independent variable, whereas three profitability ratios (ROA, ROE, and ROS) are dependent variables, with the assistance of STATA version 2015. After going through the literature reviews, the financial performance of the firm's indicators has been identified, which are ROA, ROE, and ROS. This research use panel data to evaluate the impact of five different factors including firm size, adequacy ratio, liquidity ratio, financial leverage, and solvency ratio on the profitability, which is measured by the ROA, ROE, and ROS of six different industries in Vietnam between 2014 and 2017.

Model 1: $\mathrm{ROA}_{\mathrm{i}, \mathrm{t}}=\alpha_{0}+\alpha_{1} \times \mathrm{SIZ}_{\mathrm{i}, \mathrm{t}}+\alpha_{2} \times \mathrm{ADE}_{\mathrm{i}, \mathrm{t}}+\alpha 3 \times \mathrm{LIQ}_{\mathrm{i}, \mathrm{t}}$ $+\alpha_{4} \times \mathrm{LEV}_{\mathrm{i}, \mathrm{t}}+\alpha_{5} \times \mathrm{SOL}_{\mathrm{i}, \mathrm{t}}+\varepsilon_{\mathrm{i}, \mathrm{t}}$.
Model 2: $\mathrm{ROE}_{\mathrm{i}, \mathrm{t}}=\alpha_{0}+\alpha_{1} \times \mathrm{SIZ}_{\mathrm{i}, \mathrm{t}}+\alpha_{2} \times \mathrm{ADE}_{\mathrm{i}, \mathrm{t}}+\alpha_{3} \mathrm{x} \mathrm{LIQ}_{\mathrm{i}, \mathrm{t}}$ $+\alpha_{4} \times \mathrm{LEV}_{\mathrm{i}, \mathrm{t}}+\alpha_{5} \times \mathrm{SOL}_{\mathrm{i}, \mathrm{t}}+\varepsilon_{\mathrm{i}, \mathrm{t}}$.

Model 3: $\operatorname{ROS}_{\mathrm{i}, \mathrm{t}}=\alpha_{0}+\alpha_{1} \times \mathrm{SIZ}_{\mathrm{i}, \mathrm{t}}+\alpha_{2} \times \mathrm{ADE}_{\mathrm{i}, \mathrm{t}}+\alpha_{3} \times \mathrm{LIQ}_{\mathrm{i}, \mathrm{t}}$ $+\alpha_{4} \times \mathrm{LEV}_{\mathrm{i}, \mathrm{t}}+\alpha_{5} \times \mathrm{SOL}_{\mathrm{i}, \mathrm{t}}+\varepsilon_{\mathrm{i}, \mathrm{t}}$

Where: $\alpha_{0}, \alpha_{1}, \alpha_{2}, \alpha_{3}, \alpha_{4}$, and $\alpha_{5}$ are correlation coefficients. $\varepsilon_{i, t .}$ is error of company $i$ in year $t$.

ROA: is a dependent variable, reflecting the profitability of assets and is calculated by Profit after tax/Total assets

ROE: is the dependent variable, reflecting the profitability of equity and is calculated by Profit after tax/Equity.

ROS: is the dependent variable, reflecting the profitability of sales and is calculated by Profit after tax/Sales.

SIZ (Firm size): is the independent variable, reflecting the firm's size and is calculated by Log (Total asset).

ADE (Capital adequacy): is the independent variable, reflecting the equity ratio and is calculated by Equity/Total asset.

LIQ (Liquidity): is the independent variable, reflecting the liquidity and is calculated by Short-term assets/Shortterm liability.

LEV (Financial leverage): is the independent variable, reflecting the financial leverage and is calculated by Total liabilities/Equity.

SOL (Solvency ratio): is the independent variable, reflecting the financial leverage and is calculated by (Equity + Total liabilities)/Total liabilities.

\subsection{Research Method}

Sample collection and processing process:

Step 1: Search the list of listed companies.

Get a full list of Vietnamese companies listed on HOSE and HNX until 31/12/2017. A total of 1343 companies listed with full names, stock codes and securities transactions. Classify all companies into six different industries according to HOSE's criteria: (1) 204 wholesale and retail companies, (2) 433 service companies, (3) 91 agriculture companies, (4) 452 manufacture companies, (5) 85 transportation companies, and (6) 78 mining companies.

Step 2: Collect financial statements.

Search for audited annual financial statements and annual reports of all 1343 companies in the four years from 2014 to 2017 . The total number of reports obtained by all 1343 companies is 5372 (total observation is $1343 * 4=5372$ units).

Step 3: Calculate the value of the index and clean the data.

Calculate the profitability ratio (ROA, ROE, ROS) as dependent variables together with internal financial ratio such as firm size, liquidity, solvency, leverage, and financial adequate. This is followed by a checking step to remove specific data samples if ROA is greater than ROE or ROA cannot be calculated.

After this step, remaining observations for each industry are presented as Table 1 . 
Table 1: Research Samples

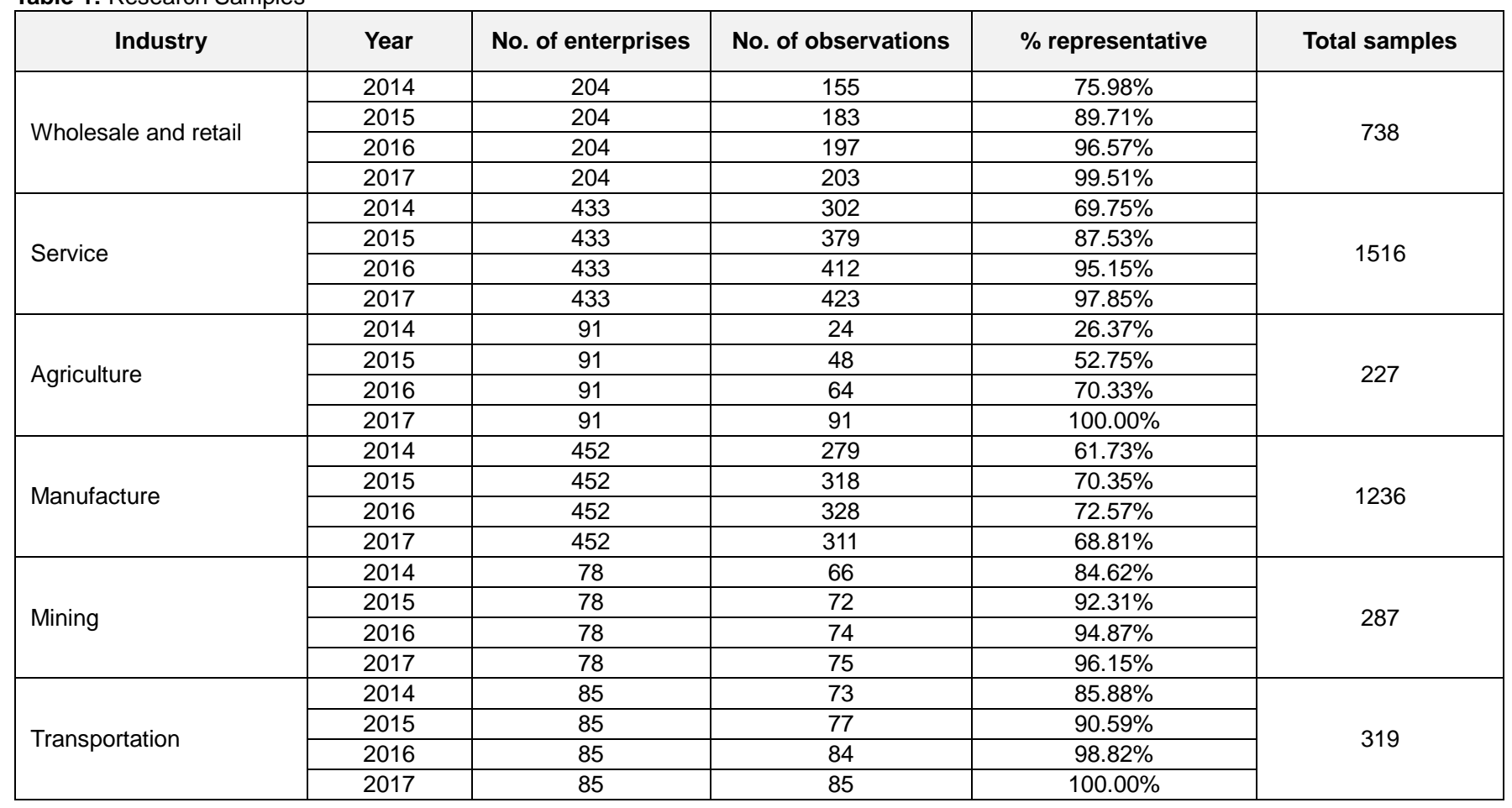

\section{Results}

\subsection{Descriptive Analysis}

In order to make a comparison of performance among six different Vietnamese industries between 2014 and 2017, it is necessary to evaluate their sales, profit, and profitability during the given period. Overall, the amount of money collected from revenue in the wholesale and retail industry accounted for the highest number as opposed to the least recorded in agriculture during four given years. Furthermore, a significant increase was seen in the number of sales in mining, transportation, and service companies while a noticeable decline was witnessed in the other companies from 2014 to 2017. Specifically, started at the highest point at approximately 4,000,000 million Vietnam Dong in 2014, the number of sales in wholesale and retail declined remarkedly by 1,000,000 million VND in 2015 before going to a low of 2,700,000 million VND in 2016. By contrast, a slight fluctuation in an upward trend was seen in the figure for service, manufacture, and transportation in comparison with a minimal decrease of around 90,000 in agriculture.

The number for profit after tax, on the other hand, is on the reverse pattern with a gradual growth seen in the manufacture, transportation, and wholesale and retail. Particularly, while transportation companies earned the lowest amount of profit at the beginning, which was replaced by agriculture enterprises since 2015, manufacture companies accounted for the highest profit. In fact, the profit after tax generated from manufacturing industries showed approximately twice and three higher than the figure for service and wholesale and retail respectively. By contrast, starting at the second-highest point of approximately 130,000 million VND in 2014, the agriculture's profit suddenly declined twice to 60,000 million VND in 2015 before reaching a low of 761 million VND in 2016. For ROA of six industries (wholesale and retail, service, agriculture, manufacture, mining, and transportation) from 2014 to 2017, in general, significantly decreased in the range from $1.09 \%$ to $9.97 \%$. Starting at the highest point of $6.8 \%$ in 2014 , the ROA of agriculture reduced slightly by $0.3 \%$ in 2015 , after which the figure witnessed a considerable decline of approximately $4.5 \%$ in the final year. While the figure for manufacture and transportation saw a strong fluctuation of from $5.64 \%$ to $-4.33 \%$ and $3.49 \%$ to $1.11 \%$ respectively, the figures for the other enterprises remained stable with a minimal decline of approximately $1 \%$ during the given period.

Figure 2 shows the changes in ROE ratios in six different Vietnamese industries from 2014 to 2017. Units are measured in percent. What stands out from the chart is that stability was seen in ROE of all industries except for transportation which witnessed a strong fluctuation of approximately $60 \%$ during the given period. Moreover, manufacturing companies always made up the highest proportion of ROE with approximately $15 \%$ in 2017, showing twice higher than the figure for wholesale and retail enterprises. ROE of mining and service industries declined by $5 \%$ and $10 \%$ respectively in 2017 from the same proportion of $8 \%$ in 2014. The difference between ROA of transportation and agriculture was tremendous with 55\% more ROE earned by agriculture. 


\section{ROE}

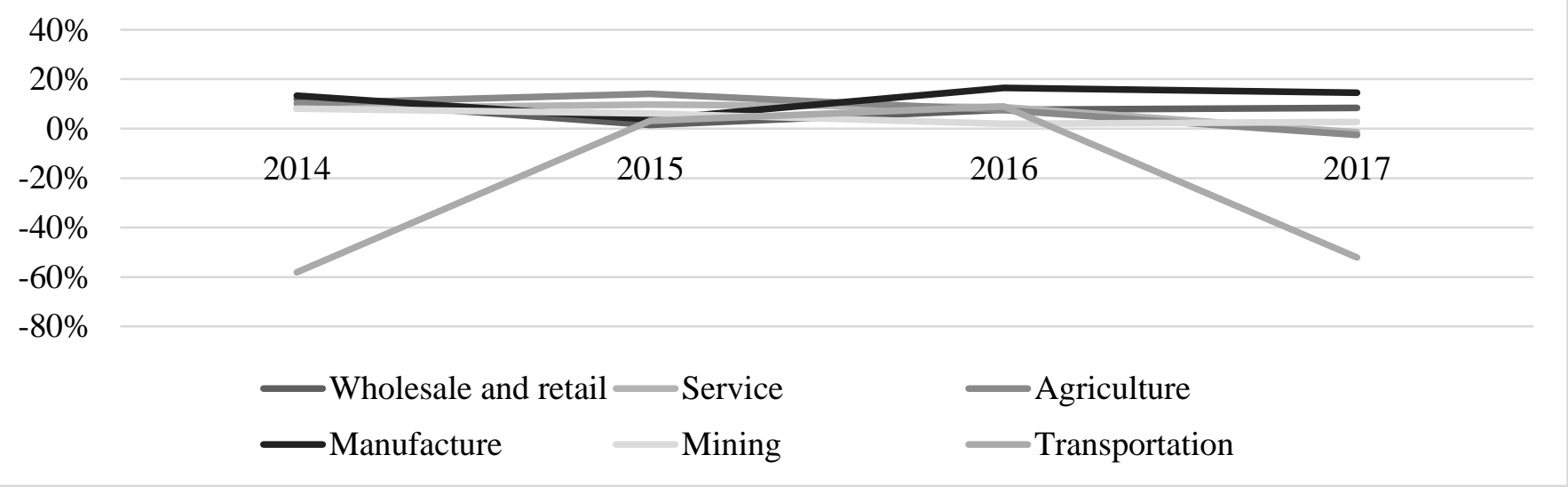

Figure 2: ROE of Six Vietnamese Industries

Also during 2014-2017, ROS increased significantly in the number of wholesale and retail, and transportation industries as opposed to an enormous decline recorded in other industries. At the beginning, agriculture' ROS made up the highest percentage of $12 \%$, mining and transportation enterprises' numbers accounted for the lowest at $-11 \%$ and $6 \%$ respectively. 2015 witnessed a tremendous decrease in ROE for all enterprises in Vietnam excepted for manufacturing with an increase of $6 \%$ while 2016 marked a reverse pattern. In 2017, ROS in manufacture and service went down by $30 \%$ and $5 \%$ in comparison with $2 \%$ and $40 \%$ growth in the figure for wholesale and retail and mining respectively.

Due to the sample collection limitation and the profitability changes in six different industries in Vietnam between 2014 and 2017, this study takes concentration on evaluating and examining the profitability in two industries only: service (1516 observations with over $90 \%$ of representative), and manufacture (1236 samples with approximately $70 \%$ of representative).

\subsection{Correlation Analysis}

Table 2 illustrates the number of observations, median, standard deviation, min, and a max of three different independent variables (ROA, ROE, and ROS) as well as five different dependent variables (SIZ, ADE, LIQ, LEV, and $\mathrm{SOV}$ ) in 1343 companies in Vietnam between 2014 and
2017. In general, while the mean of ROA is 0.01954 , that of ROE and ROS are 0.05577 and -0.0711 respectively. Additionally, the profitability in these enterprises is tremendously different with the largest amount off standard deviation recorded in the figure for ROE.

Table 2: Variable Summary

\begin{tabular}{|l|r|r|r|r|r|}
\hline Variable & \multicolumn{1}{c|}{ Obs. } & \multicolumn{1}{c|}{ Mean } & \multicolumn{1}{c|}{ Sd. } & \multicolumn{1}{c|}{ Min } & \multicolumn{1}{c|}{ Max } \\
\hline ROA & 4,330 & 0.01954 & 0.93957 & -55.316 & 1.3606 \\
\hline ROE & 4,328 & 0.05577 & 1.50629 & -51.111 & 13.2099 \\
\hline ROS & 4,315 & -0.0711 & 2.7938 & -126.96 & 18.6616 \\
\hline SIZ & 4,354 & 5.55703 & 0.68446 & 2.70501 & 8.12699 \\
\hline ADE & 4,350 & 0.4677 & 0.66247 & -18.521 & 1.25557 \\
\hline LIQ & 4,349 & 4.83845 & 102.039 & 0.0015 & 6232.18 \\
\hline LEV & 4,349 & 1.92659 & 12.6102 & 0.00016 & 667.969 \\
\hline SOL & 4,349 & 6.54463 & 182.445 & -831.27 & 10653.6 \\
\hline
\end{tabular}

Table 3 shows the correlation among variables in 1343 companies in Vietnam in the period from 2014 to 2017. What stands out from the table is that all independent variables have a low level of correlation with each other excepted for ADE and LEV with -0.6882. This would mean that it would hopefully no autocorrelation phenomenon among six different independent variables. Additionally, while SIZ, ADE, and LIQ have a positive correlation with all three profitability ratios, LEV impacts negatively on ROA, ROE, and ROS.

Table 3: Variable Correlation

\begin{tabular}{|l|r|r|r|r|r|r|r|r|}
\hline & \multicolumn{1}{|c|}{ ROA } & \multicolumn{1}{c|}{ ROE } & \multicolumn{1}{c|}{ ROS } & \multicolumn{1}{c|}{ SIZ } & \multicolumn{1}{c|}{ ADE } & \multicolumn{1}{c|}{ LIQ } & LEV & \\
\hline ROA & 1 & & & & & & \\
\hline ROE & 0.0033 & 1 & & & & & \\
\hline ROS & 0.1363 & 0.0144 & 1 & & & & \\
\hline SIZ & 0.0811 & 0.0171 & 0.0123 & 1 & & & \\
\hline ADE & 0.4762 & 0.0079 & 0.108 & -0.0209 & 1 & & & \\
\hline LIQ & 0.0129 & 0.0065 & 0.0004 & -0.0404 & 0.0703 & & \\
\hline LEV & -0.2129 & -0.006 & -0.0973 & 0.0087 & -0.6882 & -0.0177 & \\
\hline SOL & -0.0022 & 0.151 & 0.001 & 0.0278 & -0.018 & 0.0101 & -0.0009 & \\
\hline
\end{tabular}




\subsection{Regression Models}

\subsubsection{ROA Model}

Table 4 shows the regression results for the ROA model in terms of Fixed Effects, Random Effects, and Generalize Method. In order to determine and evaluate the reliability and rationality of this model, it is necessary to use the following tests:

Hausman Test to choose between FEM or REM model

Because the $\mathrm{P}_{\text {value }}$ (Hausman Test) $=0<0.05 \rightarrow \mathrm{H}_{0}$ is rejected $\rightarrow$ REM model is not suitable

In conclusion, the FEM model is suitable for Model 1.

Test of changes in error variances

Because $\mathrm{P}_{\text {value }}=0<0.05 \rightarrow$ Model 1 has changes in error variances.

Test of autocorrelation

Because $\quad P_{\text {value }}=0.0047<0.05 \quad \rightarrow \quad$ Model 1 has autocorrelation

Therefore, GMM is applied for Model 1

Sargan test of overid. Restrictions

Because the $\mathrm{P}_{\text {value }}=0.143>0.05 \rightarrow$ GMM model is suitable for Model 1.

$$
\begin{aligned}
\text { Model 1: } \operatorname{ROA}_{\mathrm{i}, \mathrm{t}}= & 3.105+0.452 \times \mathrm{SIZ}_{\mathrm{i}, \mathrm{t}}+0.154 \times \mathrm{ADE}_{\mathrm{i}, \mathrm{t}} \\
& +0.00638 \times \mathrm{LIQ}_{\mathrm{i}, \mathrm{t}}+0.00323 \times \mathrm{LEV}_{\mathrm{i}, \mathrm{t}} \\
& +0.00185 \times \mathrm{SOL}_{\mathrm{i}, \mathrm{t}}+\varepsilon_{\mathrm{i}, \mathrm{t}}
\end{aligned}
$$

\begin{tabular}{|c|c|c|c|}
\hline & (1) & (2) & (3) \\
\hline VARIABLES & FEM & REM & GMM \\
\hline \multirow[t]{2}{*}{ SIZ } & $0.118^{\star \star \star}$ & $0.118^{\star \star \star}$ & $0.452^{* *}$ \\
\hline & $(0.0196)$ & $(0.0196)$ & $(0.216)$ \\
\hline \multirow[t]{2}{*}{ ADE } & $0.985^{\star \star *}$ & $0.985^{\star \star \star}$ & $0.154^{*}$ \\
\hline & $(0.0263)$ & $(0.0263)$ & $(0.0888)$ \\
\hline \multirow[t]{2}{*}{ LIQ } & -0.000132 & -0.000132 & 0.00638 \\
\hline & $(0.000123)$ & $(0.000123)$ & $(0.00690)$ \\
\hline \multirow[t]{2}{*}{ LEV } & $0.0245^{\star \star \star}$ & $0.0245^{\star \star \star}$ & 0.00323 \\
\hline & $(0.00133)$ & $(0.00133)$ & $(0.00310)$ \\
\hline \multirow[t]{2}{*}{ SOL } & $4.65 e-05$ & $4.65 e-05$ & 0.00185 \\
\hline & $(6.93 e-05)$ & $(6.93 e-05)$ & $(0.00146)$ \\
\hline \multirow[t]{2}{*}{ L.SIZ } & & & $-2.613^{* *}$ \\
\hline & & & $(1.173)$ \\
\hline \multirow[t]{3}{*}{ Constant } & $-1.141^{* * *}$ & $-1.141^{\star \star *}$ & \\
\hline & $(0.110)$ & $(0.110)$ & 3,105 \\
\hline & & & 1,167 \\
\hline Observations & 4,325 & 4,325 & $0.452^{* *}$ \\
\hline Number of STT & 1,228 & 1,228 & $(0.216)$ \\
\hline R-squared & & & \\
\hline
\end{tabular}

Table 4: ROA Model

\subsubsection{ROE Model}

Table 5 shows the regression results for the ROE model in terms of Fixed Effects, Random Effects, and the Adjusted Fixed Effect. In order to determine and evaluate the reliability and rationality of this model, it is necessary to use the following tests:

Hausman Test to choose between FEM or REM model

Because the $\mathrm{P}_{\text {value }}$ (Hausman Test) $=0<0.05 \rightarrow \mathrm{H}_{0}$ is rejected $\rightarrow$ REM model is not suitable
In conclusion, the FEM model is suitable for Model 2.

Test of changes in error variances

Because $\mathrm{P}_{\text {value }}=0<0.05 \rightarrow$ Model 2 has changes in error variances.

Test of autocorrelation

Because $P_{\text {value }}=0.3030>0.05 \rightarrow$ Model 2 has no autocorrelation

In order to fix the error variances problem in Model 2, it is necessary to apply for this model an adjusted FEM as FEM* in Table 6.

\begin{tabular}{|c|c|c|c|}
\hline & (1) & (2) & (3) \\
\hline VARIABLES & FEM & FEM & FEM $^{\star}$ \\
\hline \multirow[t]{2}{*}{ SIZ } & -0.153 & 0.0213 & -0.153 \\
\hline & $(0.161)$ & $(0.0346)$ & $(0.0948)$ \\
\hline \multirow[t]{2}{*}{ ADE } & $-0.204^{\star *}$ & -0.0351 & $-0.204^{*}$ \\
\hline & $(0.0833)$ & $(0.0473)$ & $(0.115)$ \\
\hline \multirow[t]{2}{*}{ LIQ } & $8.87 e-06$ & $7.20 \mathrm{e}-06$ & $8.87 e-06$ \\
\hline & $(0.000509)$ & $(0.000224)$ & $(1.01 \mathrm{e}-05)$ \\
\hline \multirow[t]{2}{*}{ LEV } & $-0.00640^{* *}$ & -0.00166 & $-0.00640^{*}$ \\
\hline & $(0.00325)$ & $(0.00244)$ & $(0.00332)$ \\
\hline \multirow[t]{2}{*}{ SOL } & $-0.00215^{\star * *}$ & $0.00122^{* * *}$ & -0.00215 \\
\hline & $(0.000381)$ & $(0.000126)$ & $(0.00316)$ \\
\hline \multirow[t]{2}{*}{ Constant } & 1.027 & -0.0514 & $1.027^{*}$ \\
\hline & $(0.888)$ & $(0.195)$ & $(0.535)$ \\
\hline Observations & 4,325 & 4,325 & 4,325 \\
\hline R-squared & 0.135 & & 0.135 \\
\hline Number of STT & 1,228 & 1,228 & 1,228 \\
\hline
\end{tabular}

$$
\text { Model 2: } \begin{aligned}
\text { ROE }_{\mathrm{i}, \mathrm{t}}= & 1.027-0.153 \times \mathrm{SIZ}_{\mathrm{i}, \mathrm{t}}-0.204 \times \mathrm{ADE}_{\mathrm{i}, \mathrm{t}} \\
& +8.87 * 10^{-6} \times \mathrm{LIQ}_{\mathrm{i}, \mathrm{t}}-0.0064 \times \mathrm{LEV}_{\mathrm{i}, \mathrm{t}} \\
& -\mathbf{0 . 0 0 2 1 5} \times \mathrm{SOL}_{\mathrm{i}, \mathrm{t}}+\varepsilon_{\mathrm{i}, \mathrm{t.}}
\end{aligned}
$$

Table 5: ROE Model

\subsubsection{ROS Model}

Table 6 shows the regression results for the ROS model in terms of Fixed Effects, Random Effects, and the Adjusted Fixed Effect. In order to determine and evaluate the reliability and rationality of this model, it is necessary to use the following tests:

Hausman Test to choose between FEM or REM model

Because the $\mathrm{P}_{\text {value }}$ (Hausman Test) $=0.0732>0.05 \rightarrow \mathrm{H}_{1}$ is rejected $\rightarrow$ FEM model is not suitable

In conclusion, the REM model is suitable for Model 3.

Test of autocorrelation

Because $\quad \mathrm{P}_{\text {value }}=0.0047<0.05 \rightarrow$ Model 3 has autocorrelation

In order to fix the autocorrelation problem in Model 3, it is necessary to apply for this model an adjusted REM as REM* in Table 7.

$$
\begin{aligned}
\text { Model 3: } \operatorname{ROS}_{\mathrm{i}, \mathrm{t}}= & -0.949+0.117 \times \mathrm{SIZ}_{\mathrm{i}, \mathrm{t}}+0.484 \times \mathrm{ADE}_{\mathrm{i}, \mathrm{t}} \\
& -0.000899 \times \mathrm{LIQ}_{\mathrm{i}, \mathrm{t}}-\mathbf{0 . 0 0 3 1 3} \times \mathrm{LEV}_{\mathrm{i}, \mathrm{t}} \\
& +5.14 * 10^{-5} \times \mathrm{SOL}_{\mathrm{i}, \mathrm{t}}+\varepsilon_{\mathrm{i}, \mathrm{t}}
\end{aligned}
$$


Table 6: ROS Model

\begin{tabular}{|l|l|l|l|}
\hline & \multicolumn{1}{|c|}{$(\mathbf{1})$} & \multicolumn{1}{c|}{$(\mathbf{2})$} & \multicolumn{1}{c|}{$(\mathbf{3})$} \\
\hline VARIABLES & \multicolumn{1}{|c|}{ FEM } & \multicolumn{1}{c|}{ REM } & \multicolumn{1}{c|}{ REM $^{*}$} \\
\hline SIZ & $0.601^{* * *}$ & 0.148 & 0.117 \\
\hline & $(0.227)$ & $(0.101)$ & $(0.0914)$ \\
\hline ADE & $0.596^{* * *}$ & $0.507^{* * *}$ & $0.484^{* * *}$ \\
\hline LIQ & $(0.136)$ & $(0.110)$ & $(0.108)$ \\
\hline & -0.00130 & -0.00102 & -0.000899 \\
\hline LEV & $(0.00293)$ & $(0.00253)$ & $(0.00249)$ \\
\hline & 0.00365 & -0.000640 & -0.00313 \\
\hline SOL & $(0.00492)$ & $(0.00440)$ & $(0.00452)$ \\
\hline & $8.85 e-05$ & $5.45 e-05$ & $5.14 e-05$ \\
\hline Constant & $(0.000533)$ & $(0.000293)$ & $(0.000272)$ \\
\hline & $-3.699^{* * *}$ & $-1.139^{* *}$ & $-0.949^{*}$ \\
\hline & $(1.257)$ & $(0.569)$ & $(0.513)$ \\
\hline Observations & 4,304 & & \\
\hline R-squared & 0.168 & 4,304 & 4,304 \\
\hline Number of STT & 1,224 & 1,224 & 1,224 \\
\hline
\end{tabular}

\section{Conclusion and Recommendation}

\subsection{Conclusion}

From the above research results, it can be said that a significant difference can be seen in the impact of five different independent variables on ROA, ROE, and ROS. Specifically, although SIZ has a significant positive impact on ROA but the slight impact on ROS, it has a negative impact on ROE in these enterprises during the given period. Adequacy ratio, on the other hand, impacts positively on ROA and ROS but negatively on ROE. In contrast, liquidity is an indicator with positive effect in both ROA and ROE but a negative effect on the other profitability ratio. Next, financial leverage has a strong positive influence on ROA as opposed to a considerable negative impact on the others. Finally, solvency has a positive impact on ROA and ROS but the negative impact on ROE.

\subsection{Limitations}

The study is focused on the period of Vietnam's economy recovery phase between 2014 and 2017. By contrast, many international famous papers require the research time to be relatively long, and during that time the factors should not fluctuate greatly in order to produce a highly reliable research result. However, due to the limited time of stock market development in Vietnam, this paper has just studied and examined the period of four years (from 2014 to 2017) which is quite short. Moreover, during this time, the crisis of global economic finance had a significant impact on the domestic market, resulting in the strong fluctuation in Vietnam economy. This would mean that data collected from Vietnamese enterprises during the given period contains many intended risks, leading to the bias in the research results.

Secondly, empirical data is taken from the financial statements of businesses. The published industry may not yet have absolute accuracy. This may result in the deviations in building and testing regression models that show the impact financial factors on the profitability.

Thirdly, there are very few research topics on the effects of financial factors on the profitability in Vietnamese enterprises. This would result in certain limitations to make verification and comparison between this paper with other empirical studies. Therefore, this research is currently stopping at assessing and explaining the impact of five different indicators on the profitability of 1343 Vietnamese enterprises.

Finally, this paper has not taken into account the impact of macro factors such as GDP, inflation, interest rate, and tax rate nor specific industrial factors including competitors, customer preferences, the elasticity of demand by price, and the elasticity of supply by price to the profitability of 1343 companies listed in Vietnam stock market. Therefore, the research results presented have stronger influences on the internal of these enterprises than those of external users.

\subsection{Recommendation}

\subsubsection{For the State}

The State plays an important role in ensuring a stable business environment for Vietnamese enterprises, especially for published enterprises to take advantage of opportunities. This would help these enterprises to dominate the market, then promote the development of competitive advantage before improving financial performance. In order to do that, the State needs to promulgate policies with specific guidelines for using loan risks and credit strategy. It is because with high-interest rates, these enterprises will normally face with a high amount of interest expenses, leading to financial difficulties and even bankruptcy risks, especially in medium and small Vietnamese companies. Therefore, the State should implement the following actions to help domestic businesses achieve their goal of improving profitability:

Firstly, the State should regulate the economy and promote the development of Vietnamese enterprises by regulations and law enforcement relating to the use of loans at reasonable interest rates. This would hopefully help these enterprises with danger realization and potential risk prevention if they rely on debt to capital resources. Since these enterprises have not only to pay opportunity costs measured by interest expenses of using capital, but also witness a reduction in financial security because of the significant decline in liquidity and solvency.

Secondly, the State should support Vietnamese enterprises to expand production scale through labour education incentives, production and business premise sustenance, and input guarantee. This would enable Vietnamese businesses to have the ability to approach more customers and expand market shares, then tremendously increase in size before improving profitability. 


\subsubsection{For listed Vietnamese Companies}

For listed companies in Vietnam, it is extremely necessary to identify clearly different factors affecting profitability in operating the business since they cannot achieve their goals without profitable influencer recognition. Research results show that increasing the size of enterprises, is the key helping businesses increase profitability. This is because if enterprises expand their firms' size, they would allow to progress competitive advantages and dominate the market shares.

In addition, Vietnamese businesses should not rely dominantly on debts to maintain their operating capital due to two reasons. The first reason responsible for debt reluctance in enterprises is that an increase in the proportion of debt leads to a rise in financial leverage which has a strong negative impact on both ROE and ROS. Secondly, if an increase in debt is witnessed, both liquidity and solvency of businesses will decrease, effecting directly in the profitability, even leading to financial insecurity and bankruptcy.

\section{References}

Aburime, T. (2009). Determinants of bank profitability: Macroeconomic evidence from Nigeri. International Economics and Finance Journal, 4(1-2), 69-91. https://doi.org/10.2139/ssrn.1231064. Retrieved from http://ssrn.com/abstract=1231064

Ahmad, N., Salman, A., \& Shamsi, A. (2015). Impact of financial leverage on firms' profitability: An investigation from cement sector of Pakistan. Research Journal of Finance and Accounting, 6(7), 75-80. https://ssrn.com/abstract=2603248.

Alshatti, A. S. (2015). The effect of the liquidity management on profitability in the Jordanian Commercial Banks. International Journal of Business and Management, $\quad$ 10(1), $62-71$. DOI:10.5539/ijbm.v10n1p62.

Anbar, A., \& Alper, D. (2011). Bank specific and macroeconomic determinants of commercial bank profitability: Empirical evidence from Turkey. Business and Economics Research Journal, 2(2), 139-152. https://ssrn.com/abstract=1831345.

Athanasoglou, P., Brissimis, S., \& Delis, M. (2008). Bankspecific, industry-specific and macroeconomic determinants of bank profitability. Journal of International Financial Markets, Institutions and Money, 18(2), 121-136.

Babalola, Y. A. (2013). The effect of firm size on firms profitability in Nigeria. Journal of Economics and Sustainable Development, 4(5), 90-94. https://pdfs.semanticscholar.org/4143/a1f3b174a51728d 85901092b899047d97e6b.pdf.

Baumol, W. J. (1985). Productivity growth, convergence, and welfare: What the long-run data show. The American Economic Review, 76(5), 1072-1085. https://www.jstor.org/stable/1816469.

Benito, A., \& Vlieghe, G. (2000). Stylised facts on UK corporate financial health, evidence from micro data. Financial Stability Review, 1, 83-93. https://pdfs.semanticscholar.org/13c9/011fcfa27ce5cdd7 3256098551dd376271f5.pdf.

Blažková, I. (2018). Sectoral and firm-level determinants of profitability: A multilevel approach. International Journal of Entrepreneurial Knowledge, 6(2), 32-44. DOI: 10.2478/IJEK-2018-0012.

Blundell, R., Griffith, R., \& Reenen, J. V. (1999). Market share, market value and innovation in a panel of British manufacturing firms. The Review of Economic Studies, 66(3), 529-554. https://doi.org/10.1111/1467937X.00097.

Bradley, M., Jarrell, G. A., \& Kim, H. A. (1984). On the existence of an optimal capital structure: Theory and evidence. The Journal of Finance, 39(3), 857-879. DOI: $10.2307 / 2327950$.

Bromiley, P., \& Rau, D. (2016). Operations management and the resource-based view: Another view. Journal of Operations Management, 41, 95-106. https://doi.org/10.1016/j.jom.2015.11.003.

Cafef. (2018). List of listed companies in Vietnam. Retrieved August 20, 2018 ffrom http://cafef.vn/doanh-nghiep.chn

Capon, N., Farley, J. U., \& Hoenig, S. (1990). Determinants of financial performance: A meta-analysis. Management Science, $\quad 36(10), \quad$ 1137-1292. https://doi.org/10.1287/mnsc.36.10.1143.

Chamberlain, E. H. (1962). The theory of monopolistic competition: A re-orientation of the theory of value. Cambridge, MA: Harvard University Press.

Child, J. (1972). Organizational structure, environment and performance: The role of strategic choice. Journal Article, 6(1), 01-22. https://doi.org/10.1177/003803857200600101.

Cophieu68.vn. (2018). List of listed companies in Vietnam. Retrieved August 25, 2018 from https://m.cophieu68.vn/companylist.php

Cosh, A., Fu, X., \& Hughes, A. (2012). Organisation structure and innovation performance in different environments. Small Business Economics, 39(2), 301317. DOI: $10.1007 / \mathrm{s} 11187-010-9304-5$.

DeAngelo, H., \& Masulis, R. (1980, 3). Optimal capital structure under corporate and personal taxation. Journal of Financial Economics, 8(1), 3-29. https://doi.org/10.1016/0304-405X(80)90019-7.

Defee, C. C., \& Stank, T. P. (2005). Applying the strategystructure performance paradigm to the supply chain environment. The International Journal of Logistics Management, $16(1), 28-50$. https://doi.org/10.1108/09574090510617349.

Deloof, M. (2003). Does working capital management affect profitability of Belgian firms? Journal of Business Finance \& Accounting, 30(3-4), 573-588. https://doi.org/10.1111/1468-5957.00008.

Doğan, M. (2013). Does firm size affect the firm 
profitability? Evidence from Turkey. Research Journal of Finance and Accounting, 4(4), 53-59. https://www.iiste.org/Journals/index.php/RJFA/article/vi ew/4977/5060.

Dong, H. P., \& Su, J.-T. (2010). The relationship between working capital management and profitability: A Vietnam case. International Research Journal of Finance and Economics, 49, 59-67.

Ebenezer, O. O., Oma, B. W., \& Kamil, S. (2017). Bank specific and macroeconomic determinants of commercial bank profitability: Empirical evidence from Nigeria. Journal of Finance, 6(1), 25-38. https://www.ssbfnet.com/ojs/index.php/ijfbs/article/view/ $35 / 38$.

Edward, C. (1933). The theory of monopolistic competition. The Economic Journal, 43(172), 661-666.

DOI: $10.2307 / 2224511$.

Fareed, Z., Ali, Z., Shahzad, F., Nazir, M. I., \& Ullah, A. (2016). Determinants of profitability: Evidence from power and energy sector. Studia Universitatis BabesBolyai Oeconomica, 61(3), 59-78.

DOI: https://doi.org/10.1515/subboec-2016-0005.

Galbraith, J. R., \& Nathanson, D. A. (1978). Strategy implementation: The role of structure and process. St. Paul, MN: West Publishing Co.

Galunic, D. C., \& Eisenhardt, K. M. (2001). Architectural innovation and modular corporate forms, Working paper, 1-41. The Academy of Management Journal, 44(6), 1229-1249. https://www.jstor.org/stable/3069398.

Gilbert, R. (1989). Mobility barriers and the value of incumbency. In Handbook of Industrial Organization, 1 (pp. 475-535). https://doi.org/10.1016/S1573448X(89)01011-3). ScienceDirect, Elsevier.

Gill, A., Biger, N., \& Mathu, N. (2010). The relationship between working capital management and profitability: Evidence from the United States. Business and Economics Journal, 10(1), 1-9.

Goddard, J., Tavakoli, M., \& Willson, J. O. (2006). Determinants of profitability in European manufacturing and services: Evidence from a dynamic panel model. Applied Financial Economics, 15(18), 1269-1282. https://doi.org/10.1080/09603100500387139.

Grant, R. M. (1991). The resource-based theory of competitive advantage: Implications for strategy formulation. California Management Review, 33, 114135. https://doi.org/10.2307/41166664.

Grau, A. J., \& Reig, A. (2018). Trade credit and determinants of profitability in Europe. The case of the agri-food industry. International Business Review, 27(5), 947-957. https://doi.org/10.1016/j.ibusrev.2018.02.005.

Hall, M., \& Weiss, L. (1967). Does firm size affect the firm profitability? Evidence from Turkey. The Review of Economics and Statistics, 49(3), 319-331.

Hanoi Stock Exchange. (2018, 7 25). List of listed companies in Vietnam. Retrieved from https://www.hnx.vn/vi-vn/cophieu-etfs/chung-khoanny.html
Hitt, M. A., Xu, K., \& Carnes, C. M. (2015, 1). Resource based theory in operations management research. Journal of Operations Management, 41, 77-94. https://doi.org/10.1016/j.jom.2015.11.002.

Ho Chi Minh Stock Exchange. (2018). List of listed companies in Vietnam. Retrieved August 12, 2018 from https://www.hsx.vn/Modules/Listed/Web/Symbols?fid=1 8b12d5d2d554559bf10eeb90304ff2e

Huang, G., \& Song, F. M. (2006, 8 13). The determinants of capital structure: Evidence from China. China Economic Review, 17(1), 14-36. https://doi.org/10.1016/j.chieco.2005.02.007.

Jumono, S., Sugiyanto, \& Mala, C. M. (2019). Determinants of profitability in Banking industry: A case study of Indonesia. Asian Economic and Financial Review; Karachi, 9(1), 91-108.

DOI: 10.18488/journal.aefr.2019.91.91.108.

Kuenne, R. E. (1967). Monopolistic competition theory: studies in impact: essays in honor of Edward $H$. Chamberlin. New York: John Wiley.

Lazaridis, I., \& Tryfonidis, D. (2006). Relationship between working capital management and profitability of listed companies in the Athens Stock Exchange. Journal of Financial Management and Analysis, 19(1), 26-35. http://ssrn.com/abstract=931591.

Lenz, R. T. (1980). Enviroment, strategy, organisation structure, and performance: Patterns in one industry. Strategic Management Journal, 1(3), 209-226. https://doi.org/10.1002/smj.4250010303.

Miao, J. (2005). Optimal structure and industry dynamics. The Journal of Finance, 60(6), 2621-2659. https://www.jstor.org/stable/3694799.

Miles, R. E., Snow, C. C., Meyer, A. D., \& Coleman Jr., H. J. (1978). Organizational strategy, structure, and process. The Academy of Management Review, 3(3), 546-562. DOI: $10.2307 / 257544$.

Mohanty, B. K., \& Krishnankutty, R. (2018). Determinants of profitability in Indian banks in the changing scenario. International Journal of Economics and Financial Issues, 8(3), 235-240. https://ideas.repec.org/a/eco/journ1/201803-29.html.

Molloy, J. C., \& Barney, J. B. (2015). Who captures the value created with human capital? A market-based view. Academy of Management Perspectives, 29(3), 309-325. https://doi.org/10.5465/amp.2014.0152.

Nanda, S., \& Panda, A. K. (2018). The determinants of corporate profitability: An investigation of Indian manufacturing firms. International Journal of Emerging Markets, 13(1), 66-86. https://doi.org/10.1108/IJoEM01-2017-0013.

Nickell, S., \& Nicolitsas, D. (1999). How does financial pressure affect firms? European Economic Review, 43(8), 1435-1456. https://doi.org/10.1016/S00142921(98)00049-X.

Pattitoni, P., Petracci, B., \& Spisni, M. (2014). Determinants of profitability in the EU-15 area. Journal Applied Finance and Economy, 24(11), 763-775. 
https://doi.org/10.1080/09603107.2014.904488.

Peteraf, M. A. (1993). The cornerstones of competitive advantage: A resource-based view. Strategic Management Journal, 14(3), 179-191. https://doi.org/10.1002/smj.4250140303.

Robinson, J. (1933). The economics of imperfect competition. The Economic Journal, 43(172), 657-661. DOI: $10.2307 / 2224510$.

Rothschild, R. (1987). The theory of monopolistic competition: E.H. Chamberlin's influence on Industrial Organisation Theory over sixty years. Journal of Economic Studies, 14(1), 34-54. DOI: 10.1108/eb002641.

Serrasqueiro, Z. S., \& Nunes, P. M. (2008). Performance and size: Empirical evidence from Portuguese SMEs. Small Business Economics, 31(2), 195-217.

DOI 10.1007/s11187-007-9092-8.

Singapurwoko, A., \& El-Wahid, M. S. (2011). The impact of financial leverage to profitability study of non-financial companies listed in Indonesia Stock Exchange. European Journal of Economics, Finance and Administrative Sciences, 32, 136-148.

Sivathaasan, N., Tharanika, R., Sinthuja, M., \& Hani, V. (2013). Factors determining profitability: A study of selected manufacturing companies listed on Colombo Stock Exchange in Sri Lanka. European Journal of Business and Management, 5(27), 99-108. https://pdfs.semanticscholar.org/6a94/949c3afe29df5bd1 fadb5de136eb952a79cd.pdf.

Sufian, F., \& Habibullah, M. (2009). Bank specific and macroeconomic determinants of bank profitability: Empirical evidence from the China banking sector. Frontiers of Economics in China; Beijing, 4(2), 274-291.
DOI: $10.1007 / \mathrm{s} 11459-009-0016-1$.

Szymańska, E. J. (2017). The determinants of profitability of enterprises of meat industry in Poland. Acta Scientiarum Polonorum, Oeconomia, 16(3), 83-91. DOI: 10.22630/ASPE.2017.16.3.36.

Tu, T. T., \& Nguyen, U. T. (2014). Relationship between working capital management and profitability: Empirical evidence from Vietnamese listed firms. The 1 st International Conference on Finance and Economics 2014 (ICFE 2014). Ho Chi Minh: Ton Duc Thang University.

VietstockFinance. (2018). List off listed companies in Vietnam. Retrieved August 21, 2018 from https://finance.vietstock.vn/doanh-nghiep-a-z?page $=1$

Vintila , G., \& Duca , F. (2012). The impact of financial leverage to profitability study of companies listed in Bucharest Stock Exchange. Ovidius University Annals, Economic Sciences Series, 12(1), 1741-1744. RePEc:ovi:oviste:v:xii:y:2012:i:12:p:1741-1744.

Wernerfelt, B. (1984). A resource-based view of the firm. Strategic Management Journal, 5(2), 171-180. https://doi.org/10.1002/smj.4250050207.

Yüksel, S., Mukhtarov, S., Mammadov, E., \& Özsarı, M. (2018). Determinants of profitability in the banking sector: An analysis of Post-Soviet Countries. Economies, 6(3), 1-15. 10.3390/economies6030041.

Zheng, S.-Y., Liu, M.-H., \& Huang, J.-D. (2019). The influence of community structure on the diffusion of knowledge: A view based on market segmentation. International Journal of Emerging Technologies in Learning, 14(8), 97-114. DOI: 10.3991/ijet.v14i08.10397. 